\title{
Potential clinical applications of bone marrow-derived mesenchymal stem cells in bone regeneration
}

\author{
Vladislav S. Sergeev \\ R. Gorbacheva Memorial Institute of Children Oncology, Hematology and Transplantation, The St. Petersburg State I. Pavlov Medical \\ University, St. Petersburg, Russia
}

Dr. V. S. Sergeev, St. Petersburg State I. Pavlov Medical University, L. Tolstoy St. 6-8, 197022, St. Petersburg, Russia

\section{Summary}

Bone marrow (BM) contains a small resident cell population referred to as 'multipotent mesenchymal stem cells' (MSC). These adherent cells could be isolated and expanded in simple culture media and may differentiate in adipogenic or osteogenic pathway. So far an opportunity of MSC differentiation to hepatocytes, brain, or renal cells is not proven yet. Meanwhile, two potential clinical applications are considered for MSC: (1) as a tool for immune modulation in graft-versus-host disease (GVHD) and autoimmune diseases, or, (2) as a potential source of growth-promoting factors in specialized tissues. This heterogenous population may support hematopoiesis by secreting growth factors, cytokines and other biologically active substances. Upon injection, MSCs are able to migrate into damaged tissues, thus promoting their repair. However, only small MSC fraction may reach bone marrow niches following intravenous infusion. Multiple experiments with MSCs in different injury models show their ability to suppress apoptosis initiated by hypoxia, chemical agents/acidity and other deteriorating factors. This protective effect is mediated by a number of secreted growth factors, e.g., granulocyte-macrophage colony-stimulating growth factor (GM-CSF). A big number of clinical trials show high level of safety for the MSC
Phone: +7 (911) 1297580

E-mail: sergeev.vlad@gmail.com therapy. Both clinical and experimental studies demonstrated only weak immunogenic effects of allogeneic MSC upon injection into immunocompetent recipients. At the present time, injections of in vitro expanded MSCs were performed in the patients developing acute GVHD after hematopoietic stem cell transplantation (HSCT), and in some autoimmune disorders.

Over last decade, several studies concerned potentially curative effects of MSCs injected into affected bone areas in the patients with osteogenesis imperfecta (OI), a severe inherited disease with altered collagen structure resulting into increased bone fragility. Here we present a synopsis of clinical protocol aimed for assessing safety, immunogenicity, and clinical effects of MSC injected to the OI patients during corrective osteotomy. One may suggest that a minor MSC subpopulation may migrate to the damaged areas differentiating to chondrocytes and osteoblasts, and, hence, contributing to the bone repair.

\section{Keywords}

Mesenchymal stem cells, biodistribution, secreted factors, ex vivo expansion, clinical applications, osteogenesis imperfecta.

\section{Introduction}

In vitro expanded mesenchymal stem cells (MSCs) are currently tested as a promising tool for, e.g., prophylaxis of acute graft-versus-host disease (aGvHD) and organ rejection. More recent studies are performed, concerning feasibility of MSC-based therapies in heart insufficiency and acute renal failure [108]. Despite multiple studies, the main problem is to choose optimal and standard growth supplements in order to obtain reproducible results of the differentiation experiments. Meanwhile, much more expectations are connected with their abilities of in vitro differentiation into various specialized cell types. Two main pathways are easily detected under conventional culture conditions, i.e., adipogenic and osteogenic differentiation modes. Moreover, some specific growth factors may drive MSC to differentiate into the cells of other lineages, e.g., hepatocytes, brain, or renal 
cells. There are, however, some doubts on reproducibility of such trans-differentiation events for a sufficient fraction of proliferating MSCs.

Most clinical trials with MSC injections are aimed for treatment of autoimmune and chronic inflammatory disorders [19]. Moreover, these cell populations are regarded as a potential source for regeneration of hematopoietic and other tissues, due to a number of biologically active factors produced by MSCs, as shown by in vitro and in vivo studies [55].

\section{Bone marrow-derived MSCs}

Bone marrow (BM) represents a reservoir of different-type stem cells and precursor cells. Along with hematopoietic stem cells, the marrow contains a cell population which was previously referred to as 'mesenchymal stromal cells', 'bone marrow stromal cells', or 'marrow multipotent mesenchymal stem cells' [31]. All these denominations are covered with an acronym 'BM MSC'. These cells comprise a small fraction (0.001 to $0.01 \%)$ of the entire BM nucleated population, but they could be isolated and subject to expansion on the basis of their ability to adhere to different surfaces [18]. BM MSC are multipotent and are able to differente into precursors of osteoblasts, adipocytes and chondrocytes [74]. This heterogenous cell population takes active part in hematopoietic regulation, by secreting growth factors, cytokines and other biologically active substances, as well as by intercellular and cell/matrix interactions. BM MSCs exhibit spindle-like morphology, CD73, CD90 and CD105 expression, along with negativity for hematopoietic cell markers (CD45, CD34, CD14 etc.). Numerous studies have shown that the ex vivo expanded MSCs, by systemic or local injection, are able to migrate into damaged tissues and organs and actively participate in tissue repair processes [11;77;93,98;107]. Moreover, BM MSC possess low immunogenic potential and suppress immune response, both in vitro and in vivo $[2,45,47,94]$.

Historically, MSCs were for the first time isolated from bone marrow. Nevertheless, in further studies, MSC with similar characteristics were obtained from other organs and tissues, including subcutaneous fat, umbilical blood, placenta etc. [39,57]. Morphology, phenotype and functional properties of MSC from other sources are largely similar to BM MSC.

MSC abilities for a multi-lineage differentiation are actively studied since their discovery by A.Ya.Friedenstein in 60's of XX century [1]. Numerous studies have demonstrated that the ex vivo cultured MSCs are able for in vitro and in vivo differentiation to the terminally differentiatiated cells of mesenchymal lineage, e,g, osteoblasts/osteocytes, chondrocytes, adipocytes, myocytes and stromal cells that may support hematopoiesis $[9,10,14,20,21,37,76]$.

There are some problems with in vivo fate of the in vitro expanded MSCs isolated for subsequent therapeutic use. In fact, sufficient complement-mediated MSC cytotoxicity and lysis were revealed following their short-term in vitro treatment with fresh isologous serum [63]. This cytotoxic effect was abolished by the serum pretreatment with anti-C 5 monoclonal antibody (Eculizumab), or divalent ion deprivation.
Therefore, one should expect sufficient loss of survival for intravenously infused MSCs, as it was shown in previous studies, thus sufficiently changing their homing pattern and biological activity. Moreover, a big part of infused MSCs is entrapped in small vessels of lungs and, therefore, does no reach hematopoietic tissues or other target regions [43]. As a result, only small MSC fraction may reach bone marrow niches while homing in lungs spleen etc. Hence, MSC persistence in the body is rather short-timed, with only small amounts residing for months.

\section{Animal models}

Most studies concerning distribution of ex vivo cultured and post-labeled human MSCs after their intravenous administration to animals (i.e., mice with immune deficiency) have shown that a vast majority of the cells was captured and entrapped in lungs within 15 to $30 \mathrm{~min}$. [48]. Meanwhile, halflife time of the cells in lungs was about 24 hours. Histological examination of the lung samples demonstrated MSC-associated embolism in small arteries, along with progressing apoptosis of the most MSCs. [49]. Only a small fraction of injected cells entered blood circulation, being distributed into different organs, e.g., liver, lungs, kidneys, bone marrow et al. At 48 and 96 hours post-injection, respectively, $0.04 \%$ and $0.01 \%$ of initially applied cells were detectable in these organs and tissues. Thereby, the MSC distribution patterns did not differ from those obtained upon injection of human mammary carcinoma cells [48].

The data concerning long-term MSC persistence showed sufficient inter-study differences, probably, due to the label type chosen. In some studies, human cells were revealed only in spleen by the day 7, but not after 3 months [44]. Meanwhile, other detection techniques have shown that small MSC amounts may persist in bones, cartilages, bone marrow, muscles and spleen for several months [3].

\section{Human studies}

By now, only few studies were dedicated to distribution of MSC following intravenous injection to humans. Appropriate results confirm a similar distribution pattern, i.e., cell entrapment in pulmonary microvascular network early after infusion, and probable differences in their subsequent recirculation, which may be connected with species-specific anatomical and physiological features, disease states in the persons under study, or alternative techniques of cell detection. E.g., radioindium-labeled MSCs were infused i/v to the patients with liver cirrhosis [22]. At early terms, the cells were accumulated in lungs, however, they were displaced to liver and spleen within hours and days. Radioactivity in lungs diminished, respectively, from $33.5 \%$ to $2 \%$ in lungs, while being increased in spleen from $2 \%$ to $42 \%$.

Long-term persistence of allogeneic MSCs was studied in patients with acute graft-versus-host disease (GvHD), by means of donor DNA detection in biopsies form different tissues [100]. In 8 of 13 patients, minimal amounts of donor DNA were detected in one or more samples obtained, 
mostly, from lungs, spleen, lymph nodes and small intestine, within 50 days after last infusion. Quantitative analysis has shown that the donor cell numbers in these tissues did not typically exceed $0.001 \%$.

\section{Safety of therapy with ex vivo cultured MSC}

Ex vivo grown MSC from bone marrow and other sources have been actively tested in clinical trials, from the 1990s. At the present time, more than 400 clinical trials are registered in different databases [51]. Analysis of short- and longterm effects revealed a high-level safety of this therapeutic approach. A special meta-analysis concerned adverse effects after MSC injections performed in 1012 patients enrolled into 26 clinical studes [42]. Allogeneic HLA-compatible, or HLA-mismatched MSC were infused in $56 \%$ of the studies included. No correlations were revealed between MSC infusions and acute posttransfusion reactions, organ-specific complications, infections, development or progression of malignancies and/or lethal outcomes. A transitory fever was the only significant adverse effect that could be ascribed to MSC injections. It was documented for 30 to $40 \%$ of the cases in randomized studies, when applying both autologous and allogeneic cells.

\section{Underlying mechanisms of MSC therapeutic effects}

One may discern two main mechanisms underlying the therapeutic effects observed after MSC injection. The first mechanism implies MSC proliferation and differentiation into various cell types which replenish and/or replace functional cells lost due to certain pathological process or medical influence. The second mechanism presumes trophic and immunomodulatory effects exerted by MSC upon surrounding and remote cells and tissues, due to wide-spectrum secretion of biologically active substances as well as microvesicles and apoptosis products released into extracellular space intercellular exchange. Immediate therapeutic effects observed upon BM MSC injection are mostly mediated by soluble factors (cytokines, growth factors, low-molecular compounds) produced by the BM MSC or other cells upon their interactions with BM MSC $[2 ; 64]$ and microvesicules, and due to close contacts, e.g., with hematopoietic cells [72, 12, 102].

MSCs secrete a number of soluble substances (cytokines, growth factors, low-molecular compounds) which exert di- rect or indirect influence upon surrounding and distant cells and tissues. The MSC-mediated endocrine and paracrine effects may be divided into trophic and immunomodulatory ones. [11]. In turn, the MSC trophic effects are underlied by their ability to prevent apoptosis of neighbor cells, induce proliferation and differentiation of endogenous precursor cells, as well as to initiate angiogenesis. At the present time, some distinct factors mediating MSC effects are partially identified (Table 1).

Immunomodulatory activity of MSC is exerted via inhibition of CD4+and CD8+ T cell, and NK cell proliferation, decreased Ig production by plasmocytes, inhibition of dendritic cell proliferation, and stimulation of regulatory $\mathrm{T}$ cell proliferation. These effects are performed by a number of enzymes and secreted factors: prostaglandin E2 (PGE-2), soluble leukocyte antrigen (HLA-G5), hepatocyte growth factor (HGF), inducible NO synthase (iNO), indole-2,3-deoxygenase (IDO), transforming growth factor beta (TGF-b), leukemia-inhibiting factor (LIF), and interleukin 10 (IL-10).

Multiple experiments concerning MSC effects in acute injury models of different organs, tissues and cells have shown that MSCs are able to prevent massive apoptotic cell death. MSC suppress apoptosis initiated by hypoxia, chemical factors/acidity, mechanical damage, and ionizing irradiation [62]. This protective effect is mediated by some key secreted molecules. e.g., vascular endothelial growth factor (VEGF), hepatocyte growth factor (HGF), insulin-like growth factor (IGF-I), stanniocalcin-1, transforming growth factor-beta (TGF-b), and granulocyte-macrophage colony-stimulating growth factor (GM-CSF).

Extracellular matrix molecules, (VEGF), (IGF-I), placental growth factor (PIGF), macrophage chemotaxis factor-1 (MCP1), fibroblast growth factor (bFGF), and interleukin 6 (IL-6), secreted MSC are initiating angiogenesis. In turn, restoration of blood circulation in the injured tissues maya represent a fundamental factor for their successful reconstitution.

Endogenous precursor cells activated and attracted to injured sites from the surrounding tissues are playing a major role in repair processes. They migrate to the damaged areas and are the main source of the newly formed differentiated cells replacing the lost ones. Nevertheless, the efficiency of this process is often insufficient, especially in cases of severe injuries, when an external stimulation is necessary. MSC-secreted factors, e.g., stem cell factor (SCF), leukemia-inhibiting factor (LIF), M-CSF, stroma-derived factor (SDF-1) and angiopoetin-1 favor cell survival, proliferation and differentiation of tissue-specific endogenous precursor cells.

Table 1. Immunomodulatory factors released by in vitro cultured MSCs

\begin{tabular}{|l|l|}
\hline Biological effects & Molecules produced [references] \\
\hline Apoptosis prevention & $\begin{array}{l}\text { VEGF [81,99], HGF [81,99], IGF-I [99], Stanniocalcin-1 [8], } \\
\text { TGF-b [81], bFGF [81], GM-CSF[81] }\end{array}$ \\
\hline Immunomodulatory effect & $\begin{array}{l}\text { PGE-2 [58,92], TGF-b [16,92], HGF [16], mpCCL2 [79], ID0 } \\
\text { [60], iN0S [86], HLA-G5 [65], LIF [15,66] }\end{array}$ \\
\hline
\end{tabular}




\begin{tabular}{|l|l|}
\hline Biological effects & Molecules produced [references] \\
\hline Antifibrotic effect & bFGF [95], HGF [95], Adrenomedullin [50] \\
\hline $\begin{array}{l}\text { Stimulation of proliferation and differentiation } \\
\text { of endogenous precursor cells }\end{array}$ & $\begin{array}{l}\text { SCF, LIF IL-6, M-CSF [28,56], SDF-1 [70,96], Angiopoietin-1 } \\
{[70]}\end{array}$ \\
\hline $\begin{array}{l}\text { Angiogenesis stimulation } \\
\text { bFGF [40], VEGF [32,40], PIGF [40], MCP-1 [32,40], IL-6 } \\
\text { [32], extracellular matrix components [91] }\end{array}$ \\
\hline
\end{tabular}

\section{Choice of MSC donor and immuno- genicity of allogeneic MSC}

MSCs may be harvested from the patient, then expanded and returned in autologous manner. However, MSCs for autotransplants should be sometimes isolated from senior people, diseased individuals, and females with suppressed osteogenic potential. Therefore, some benefits from usage of allogeneic MSCs are supposed in a review by Kovach et al. [41]. E.g., they suppose allogeneic MSCs isolated from young, healthy males to be optimal grafts for boosting bone repair in these populations at risk. However, one should account for non-predictable immune reactions, since some animal studies suggest that use of allogeneic MSCs is not feasible owing to immune response of the recipients to transplanted MSCs.

Ex vivo cultured MSC possess a pronounced immunomodulatory activity, express modest amounts of MHC I molecules, and do not express MHC II $[5,45]$. These properties allow to suggest a low immunogenic potential of allogeneic MSC, as confirmed by some experimental studies, both in vitro and in vivo $[4,78,85]$. On other hand, proinflammatory cytokines induce higher MHC I levels, and MHC II antigen expression. [71]. In rodent experiments, it was demonstrated that systemic infusion of allogeneic MSC is accompanied by alloimmune response $[68,109]$. However, if compared with other cell types, the alloimmune response to MSC is more delayed and less pronounced, and allogeneic MSC may persist in the organism of immunocompetent recipient for a much longer time. [109].

Some cautions concerning immunosuppressive effects of allogeneic MSC transplants arise from experimental study by Prigozhina et al. [75]. Immunosuppressive properties of MSCs in vivo were tested by a well-known model of ectopic bone formation in both syngeneic and allogeneic murine recipients. MSCs from different sources were implanted with neutral bone scaffold under the kidney capsule. Bone development was observed in only the syngeneic hosts, whereas the allogeneic hosts experienced transplant rejection. This data argue for perturbed in vivo immune interactions of MSCs in allogeneic recipients.

Meanwhile clinical studies in humans have shown that allogeneic MSC could be safely injected to immunocompetent recipient without development of clinically significant alloimmune reaction $[6,26,27]$. In spite of big number of trials, there are no convincing data which presume production of donor-specific antibodies (including HLA-specific) after sys- temic injections of allogeneic MSC. Moreover, no sufficient differences were detectable, when comparing therapeutic efficiency of auto- and allogeneic MSC $[5,26]$. Hence, the issue of MSC immunogenicity and its influence upon therapeutic efficiency with allogeneic MSC remains unsolved and needs further studies.

\section{Directed MSC migration}

It was shown in several experimental animal studies that, at least, a part of MSCs arriving from lungs may migrate to the foci of injury/inflammation [7, 35, 36] and, hence, accumulate at these sites in greater concentrations than in intact tissues. A key role in the directed migration of MSC belongs to chemokines and adhesion molecules. Their induced expression is initiated in the cells involved into inflammation at the injured sites. At least, a fraction of MSCs (3-4\%) is expressing the CXCR4 receptor which provides cellular chemotaxis along SDF-1 concentration gradient [106], thus playing a key role in migration of other cell types, e.g., hematopoietic and endothelial populations [44, 90]. Along with CXCR4, the MSC express receptors for other chemokines. i.e., CCR1, CCR4, CCR7, CCR10, CCR9, CXCR5 и CXCR6 [29, 101]. Directed MSC migration is performed due to the expression of some adhesion molecules on their surface, i.e., integrin beta1, and integrin alpha4. Inhibition of these molecules blocks the migration process $[33,84]$. Moreover, MSC may express a number of matrix metalloproteinases, thus allowing the cells to migrate in extracellular matrix [83].

\section{Time course of osteogenic effects in regenerating bones and MSC-derived factors}

Bone injury and its repair is a multistep process which exhibits different patterns of bioactive molecules released at the damaged site, especially, in the cartilage growth plate which is the bone growth area in children. Depending on the terms post-fracture, osteogenesis strongly depends on specific growth factors released by cellular microenvironment [13]. The authors discern four stages of repair mechanisms, i.e., inflammatory, fibrogenic, osteogenic and remodeling phases. Inflammatory cytokines, e.g., TNF alpha, IL- beta exert strong regulating effects at the initial post-injury phase, whereas chemokines, PDGF and FGF2 are active at the fibrogenic stage. Specifically, transforming growth factor $\beta 1$ (TGF $\beta 1$ ) plays a critical role in bone reconstitution due to its potent chemotactic and proliferative effect on mesenchymal 
stem cells, therefore promoting accumulation of bone-forming tissues at the injured site. In addition, TGF $\beta 1$ induces production of ECM components, e.g., collagen, osteopontin, and alkaline phosphatase from MSCs and osteoblasts. Bone morphogenetic proteins (BMPs) also belong to the TGF- $\beta$ superfamily and are additional growth factors for mesenchymal stem cells that induce both osteogenesis and angiogenesis. For more recent data see a review by Zigdon-Gilad et al. [110]. By these mechanisms, BMPs are involved at all phases of the cartilage and bone repair.

Likewise, several angiogenesis factors are important at the osteogenic response. MSCs may release angiogenic factors [angiopoietin (Ang)-1, -2, Anglike-1, -2, -3, -4, VEGF, and fibroblast growth factor-2] that attract resident MSCs and promote local angiogenesis, a conditio sine qua non for renewal of osteoid structures [73].

\section{Potential MSC applications in osteogenesis imperfecta}

Some studies concerned engraftment of ex vivo cultured syngeneic MSC in murine model of osteogenesis imperfecta (OI), an inherited collagen synthesis disorder. Upon postnatal intravenous injection of the MSCs, only negligible numbers of osteoblasts $(<2 \%)$ of donor origin were detected in recipient mice $[17,71]$, or their total absence [34]. Moreover, despite minimal amounts of donor osteoblasts (ca.1\%) in homozygous oim/oim mice, no signs of a 2 collagen type I chains were found in the bone tissue samples [71]. These data are indicative for a potentially low efficiency of MSC infusions, as a replacement cell therapy in (OI). Worth of note, despite lacking MSC engraftment, the oim/oim mice exhibited a notable increase in linear bone growth and total body mass as compared with mice from control group. The workers presumed this effect to be determined by chondrocyte proliferation in epiphyseal plates of the tubulous bones, due to some indirect paracrine effects of the MSCs injected.

Despite low efficiency of the MSC systemic infusions to intact bones, the MSC engraftment rates may be sufficiently higher if delivered to regenerating bone after its fracture. This depends on the well-known active migration of mesenchymal precursor cells from periost and other surrounding tissues, e.g., to blood circulation and repairing bone areas [87]. Several studies have shown that a small number of intravenously injected MSC could migrate to the fracture zones, later being differentiated to chondrocytes and osteoblasts which took active part in the tissue repair and bone callus formation [25, 69]. Thereby, the CXCR4-expressing MSC represented the only directly migrating population [25]. The MSC provided a significant improvement of the fracture healing, due to increased mass of regenerating chondrogenic and bone tissues, and development of harder bone calluses, when compared with control, non-MSC-treated, mice. Along with direct differentiation to chondroblasitc and osteoblastic cells, the MSCs exerted a favorable effect upon repair, by means of local and systemic immunomodulatory and trophic effects promoting further survival and proliferation of endogenous mesenchymal precursor cells, faster transition from inflam- mation to the callus formation, and, hence, accelerated consolidation of the bone fragments $[25,54,69,80]$.

Hence, therapeutic effects of systemic MSC infusions in the patients with OI after corrective osteotomy may proceed via several different mechanisms:

- The MSCs may exert their systemic trophic effect which causes enhanced proliferation of chondrocytes of the epiphyseal plates, and, subsequently, increased linear bone growth in pediatric patients.

- A minor MSC subpopulation may migrate to the damaged areas, differentiate to chondrocytes and osteoblasts, and, hence, participate in bone repair processes. Moreover, the de novo produced osteoblasts of donor origin in the bone callus may represent a significant part of total osteoblastic population in regenerating bone [25], and, therefore, produce sufficient amounts of type I collagen. The latter may contribute to mechanical strength of the tubulous bones subjected to osteotomy. Consequently, it may result in decreased frequency of fractures, and prevent recurrent bone deformities.

- Both systemic and local immunomodulatory and trophic effects exerted by the migrating cells promote reduction of inflammatory phase and more rapid development of the bone callus, as well as survival and proliferation of mesenchymal precursor cells, increased mass of chondrogenic and osteogenic tissues participating in the bone repair, thus, finally, leading to eventual decrease of the bone consolidation terms following osteotomy.

\section{Pre-clinical studies of MSCs in bone regeneration models}

A comprehensive systhematic review of 20 selected preclinical studies involving large animals (dogs, sheeps, rabbits) with bone defects was published by a group from China [52]. The experimental procedures included, mainly, implants of scaffolds seeded by fat- or bone marrow-derived MSCs, or direct injections of MSC into the injury site. Observation terms varied between 12 and 36 weeks. Forest plot data analysis showed a significant beneficial effect of stem cell therapy in increasing new bone formation tested by different visualization techniques (17.8\%; 95\% CI, 10.54; 25.03; $\mathrm{P}<0.001$ ), and confirmed by available data on increased bone mineral density following MSC treatment. Some differences depended on cellularity of the transplant. Usage of matrix scaffolds seemed to be more effective than direct cell injection. Noteworthy, the effects of MSC treatment proved to be diminished after 12 weeks post-transplant, thus presuming a need for repeated cell injections at longer terms.

\section{Preliminary clinical data}

At present time, only two study groups have published data on clinical application of systemic MSC infusions for treatment of OI patients. In the study by Horwitz et al. [30], six patients with type $3 \mathrm{OI}$, after previous allogeneic bone marrow transplantation, were subjected to double MSC in- 
fusions fron the same donors at a dose of $1-5 \times 106$ cells $/ \mathrm{kg}$ body weight. In five patients of six, an accelerated growth dynamics was observed within 4 to 6 weeks after infusions. The improvement comprised $60 \%$ to $94 \%$ (a mean of $70 \%$ ) of the expected median values for healthy sex- and agematched children. As compared with $0 \%$ to $40 \%$ (a mean of $20 \%$ ), that were observed during 6 месяцев preceding the infusions. Horwitz and colleagues have also launched a more extensive study with 15 patients, who received regular infusions of allo- or syngeneic MSC once every 4 months over a total of 20 months. However, the results of this study are not published so far.

Another group of investigators has published two cases of allogeneic MSC infusions to 2 patients with OI (types III and IV), who were diagnosed prenatally [24, 46]. This study had some specific features:

- Allogeneic MSC derived from fetal liver were used as a grafting material due to their higher potential for proliferation and multilineage differentiation, as compared with MSC from adults [23].

- The first infusion was performed at the intrauterine stage (into the umbilical vein), hence, the infused cells got directly to systemic circulation, avoiding the pulmonary circuiut.

- At the moment of MSC infusions, both patients had multiple bone fractures, according to ultrasound data.

Probably, these aspects of the study could predetermine high level of chimerism (up to 7-15\%) in osteoblastic cellular lineage as seen from the bone sample testing. However, high chimerism levels proved to be transient and further dropped down to undetectable values. In both cases, the infusions were accompanied by total healing of the fractures and successful deliveries. Repeated infusions were performed post partum, at the age of 8 years and 19 months, primarily, due to stunting growth. MSC infusions were associated with resuming growth in both patients.

We have not find any works concerning systemic MSC infusions for immediate treatment of children with OI after corrective osteotomy of femoral and/or tibial bone.

\section{Rationale and design of the ongoing study}

Despite some favorable effects of the biphosphonate-type bone resorption inhibitors (e.g., increased bone mineral density and decreased fracture incidence), there is no effective treatment aimed for restoration of linear bone growth and prevention of the bone deformities in the patients with childhood OI. Moreover, the biphosphonate therapy is poorly compatible with corrective osteotomy, since these drugs suppress bone tissue remodeling, thus causing delayed healing of the osteotomy site [61]. Hence, a clear need for novel therapeutic approaches still exists for this group of patients.

On the basis of experimental and primary clinical data, we suggest that allogeneic MSC infusion should be a safe procedure, and, moreover, a stimulation of chondrocyte prolifera- tion could be achieved in epiphyseal plates of the long bones, due to paracrine/endocrine effects of MSC infusions, thus leading to restoration of linear bone growth in pediatric patients with moderate-to-severe clinical forms of OI. Increase of the bone mass, improved quality of osteogenic tissue and its higher mineral density could be achieved via systemic and local immunomodulatory and trophic effects of MSCs, their differentiation to chondroblastic and osteoblastic lineages, and probably, due to sufficient synthesis of normal type I collagen. These effects will cause increased strength of the bones subjected to surgical interventions. In clinical aspects, these events will lead to decreased incidence of bone fractures, accelerated consolidation and lower recurrence of bone deformities.

Allogeneic MSC are planned to be used in the present study. This is due to ability of such donor cells to produce normal type I collagen, if differentiating to osteoblastic lineage. On the other side, it is well known that occurrence of alloimmune response may be a limiting factor of cell therapy efficiency, since its long-range goal is to replace and restore cells and tissues by the donor cells. Therefore, an alloreactive immune response may prevent a long-term persistence of the donor osteoblasts and normal collagen sysnthesis. Neverthless, MSCs are known to be only weakly immunogenic, and so far, according to numerous clinical trials with allogeneic cells, there are no sufficient clinical data indicative for a pronounced alloimmune response arising after systemic MSC injection (for details see under "Allogeneic MSC immunogenicity"). Moreover, some experimental results show that, in cases of alloimmune reactions towards MSC, such response is relatively delayed, and, hence, a period from cell injection to immune rejection signs is prolonged up to 20 days [109]. This time interval is sufficient for MSC migration to the osteotomy area and their differentiation to osteoblasts actively producing normal type I collagen. Besides that, we suppose that a therapeutic action of injected MSCs is determined, mainly, by systemic and local trophic/immunomodulatory effects that are produced by the donor cells within short terms post-infusion. Hence, the time intervals necessary for the basic therapeutic actions of the MSCs (hours to days post-injection), are not interfering with their probable rejection terms, due to allo-immune mechanisms (ca.20 days following the cell infusion).

To reduce probability of MSC rejection, we are planning to use the cells from HLA-matched bone marrow donors (either related, or unrelated persons from available marrow donor registries). In case of their lack, we are suggesting to employ partially compatible, and, at least, incompatible donors. For HLA-incompatible donor/recipient pairs, the patients will be monitored for specific anti-HLA antibodies.

So far, there are no recommendations concerning choice of optimal dosage and regimens for MSC injections. In vast majority of clinical studies with MSC, the doses of $1-2 \times 10^{6}$ cells/kg weight were used. Even higher cell doses were applied in some trials $\left(8-10 \times 10^{6}\right.$ cells $\left./ \mathrm{kg}\right)$, without any adverse effects $[38 ; 59,104]$. The data about dependence of treatment efficiency on the cell dosage are rather controversial. A series of pharmacodynamic studies has shown that a dose of $1 \times 10^{6}$ cells/kg exerted a weak, but statistically significant therapeu- 
tic effect in a model of myocardial infarction in hamsters [89]. The same study yielded maximal therapeutic effects when using much higher cell doses $\left(40 \times 10^{6}\right.$ cells $\left./ \mathrm{kg}\right)$. Meanwhile, some clinical results suggest that higher MSC doses are not more effective, when treating acute graft-versus-host disease [53]. Moreover, MSCs are rather large-sized cells which are prone to aggregation, thus, being able of blocking blood flow in small pulmonary vessels upon intravenous infusion. Therefore, the $\mathrm{i} / \mathrm{v}$ infusions at abundant MSC concentrations may be accompanied by a risk of clinically significant embolization of the small blood vessels in lungs.

Due to proven clinical safety of i.v. MSC infusions at the dose scale of 1 to $10 \times 10^{6}$ cells $/ \mathrm{kg}$, a therapeutic window between the cell infusions, and time required for potential immune rejection, as well as economic considerations, our present study provides for two infusions of allogeneic MSCs per patient. The allogeneic MSCs should be applied on days +1 and +10 after a corrective osteotomy at a dose of $5 \times 106$ cells per $1 \mathrm{~kg}$ body weight.

Primary goal of our study is to assess safety of cryopreserved, ex vivo cultured allogeneic MSCs after intravenous infusion of the cells to the patients with osteogenesis imperfecta, evaluating acute infusion toxicity and immunogenicity (anti-HLA antibody production). Secondary goal is to study potential therapeutic effects of allogeneic MSC infusions in the patients by clinical parameters, e.g., decreased incidence of bone fractures within 2 years after MSC infusions; acceleration of linear bone growth rates, accelerated bone fragment consolidation, and increased mineral density of bone tissue, as well as laboratory markers of osteogenesis. This will be a prospective open-label single-center trial, Phase 1-2. Allogeneic MSCs will isolated from the marrow of HLA-compatible related, or unrelated donors, in order to obtain ex vivo cultured MSCs. A total of 15 patients with osteogenesis imperfecta will be subjected to infusions of cryopreserved, ex vivo cultured allogeneic MSCs $24 \mathrm{~h}$ after a corrective osteotomy of femoral and/or tibial bone, at two doses of $5 \times 10^{6}$ cells/kg, with an interval of 10 days. Toxicity and potential efficiency of the treatment will be evaluated. A five-year observation period after MSC infusions is scheduled.

\section{Conclusion}

Multipotent mesenchymal stem cells (MSC) represent an adherent, easily cultured cell population from different sources which is recognized by specific markers and secretes a number of growth-promoting factors and cytokines.

Bone marrow-derived MSCs may differentiate to adipogenic or osteogenic direction. The fate and viability of infused MSCs is not studied in details, like as their in vivo differentiation abilities. The injected MSCs are shown to improve tissue repair processes and modulate adverse immune reactions, such as severe GVHD post-transplant.

Therefore, a novel protocol is proposed for treatment of osteogenesis imperfecta (OI), based on MSC injections performed during corrective bone plastics in the OI patients. A small group of cases should be observed for assessment of toxicity, immunogenicity and duration of potential therapeutic effects produced by MSC infusions.

\section{Conflict of interests}

No conflict of interests is declared.

\section{References}

1. Afanasyev BV, Elstner EE, Zander AR, A.J.Friedenstein, founder of the mesenchymal stem cell concept. Cell Ther Transplant 2009; 1(3):35-38.

2. Aggarwal S, Pittenger MF. Human mesenchymal stem cells modulate allogeneic immune cell responses. Blood 2005;105:1815-22.

3. Allers C, Sierralta WD, Neubauer S, Rivera F, Minguell JJ, Conget PA. Dynamic of distribution of human bone marrow-derived mesenchymal stem cells after transplantation into adult unconditioned mice.Transplantation. 2004;78(4):503-508.

4. Amado LC, Saliaris AP, Schuleri KH, St John M, Xie JS, Cattaneo S, Durand DJ, Fitton T, Kuang JQ, Stewart G, Lehrke S, Baumgartner WW, Martin BJ, Heldman AW, Hare JM. Cardiac repair with intramyocardial injection of allogeneic mesenchymal stem cells after myocardial infarction. Proc Natl Acad Sci USA 2005;102(32):11474-11479.

5. Ankrum JA, Ong JF, Karp JM. Mesenchymal stem cells: immune evasive, not immune privileged. Nat Biotechnol. 2014;32(3):252-260.

6. Ascheim DD, Gelijns AC, Goldstein D, Moye LA, Smedira N, Lee S, Klodell CT, Szady A, Parides MK, Jeffries NO, Skerrett D, Taylor DA, Rame JE, Milano C, Rogers JG, Lynch J, Dewey T, Eichhorn E, Sun B, Feldman D, Simari R, O'Gara PT, Taddei-Peters WC, Miller MA, Naka Y, Bagiella E, Rose EA, Woo YJ. Mesenchymal precursor cells as adjunctive therapy in recipients of contemporary left ventricular assist devices.Circulation. 2014;129(22):2287-2296.

7. Assis AC, Carvalho JL, Jacoby BA, Ferreira RL, Castanheira P, Diniz SO, Cardoso VN, Goes AM, Ferreira AJ. Time-dependent migration of systemically delivered bone marrow mesenchymal stem cells to the infarcted heart. Cell Transplant. 2010;19(2):219-230.

8. Block G, Ohkouchi S, Fung F, Frenkel J, Gregory C, Pochampally R, DiMattia G, Sullivan DE, Prockop DJ. Multipotent stromal cells are activated to reduce apoptosis in part by upregulation and secretion of stanniocalcin-1. Stem Cells 2009;27(3):670-81.

9. Bruder SP, Jaiswal N, Haynesworth SE, Growth kinetics, self-renewal, and the osteogenic potential of purified human mesenchymal stem cells during extensive subcultivation and following cryopreservation. J Cell Biochem 1997;64:278-294.

10. Bruder SP, Kurth AA, Shea M, Hayes WC, Jaiswal N, Kadiyala S. Bone regeneration by implantation of purified, culture-expanded human mesenchymal stem cells. J Orthop Res 1998; 16:155-162. 
11. Caplan A, Dennis J. Mesenchymal stem cells as trophic mediators. J Cell Biochem. 2006 Aug 1;98(5):1076-1084.

12. Chen J, An R, Liu Z, Wang JJ, Chen SZ, Hong MM, Liu JH, Xiao MY, Chen YF. Therapeutic effects of mesenchymal stem cell-derived microvesicles on pulmonary arterial hypertension in rats. Acta Pharmacol Sin. 2014; 35(9):1121-1128.

13. Chung R, Xian CJ. Mechanisms for growth plate injury repair and potential cell-based therapies for regeneration. Journal of Molecular Endocrinology 2014;53:T45-T61.

14. Dennis J.E., Merriam A., Awadallah A., Yoo J.U., Johnstone B., Caplan A.I., A quadripotential mesenchymal progenitor cell isolated from the marrow of an adult mouse. J. Bone Miner. Res. 1999;14:700-709.

15. Di Ianni M, Del Papa B, De Ioanni M, Moretti L, Bonifacio E, Cecchini D, Sportoletti P, Falzetti F, Tabilio A. Mesenchymal cells recruit and regulate $\mathrm{T}$ regulatory cells. Exp Hematol 2008; 36(3): 309-318.

16. Di Nicola M, Carlo-Stella C, Magni M, Milanesi M, Longoni PD, Matteucci P, Grisanti S, Gianni AM. Human bone marrow stromal cells suppress T-lymphocyte proliferation induced by cellular or nonspecific mitogenic stimuli. Blood 2002;99(10):3838-3843

17. Dominici M, Pritchard C, Garlits JE, Hofmann TJ, Persons DA, Horwitz EM. Hematopoietic cells and osteoblasts are derived from a common marrow progenitor after bone marrow transplantation. Proc Natl Acad Sci US A. 2004;101(32):11761-11766.

18. Dominici M, Le Blanc K, Mueller I, Slaper-Cortenbach I, Marini F, Krause D, Deans R, Keating A, Prockop Dj, Horwitz E. Minimal criteria for defining multipotent mesenchymal stromal cells. The International Society for Cellular Therapy position statement. Cytotherapy 2006;8(4):315-7.

19. Dothel G, Raschi E, Rimondini R, De Ponti F. Mesenchymal stromal cell-based therapy: Regulatory and translational aspects in gastroenterology. World J Gastroenterol 2016;22(41):9057-9068.

20. Ferrari G, Cusella-De Angelis G, Coletta M, Paolucci E, Stornaiuolo A, Cossu G, Mavilio F. Muscle regeneration by bone marrow-derived myogenic progenitors. Science. 1998;279:1528-1530.

21. Galmiche M.C., Koteliansky V.E., Briere J., Herve P., Charbord P. Stromal cells from human long-term marrow cultures are mesenchymal cells that differentiate following a vascular smooth muscle differentiation pathway. Blood. 1993;82:66-76.

22. Gholamrezanezhad A, Mirpour S, Bagheri M, Mohamadnejad M, Alimoghaddam K, Abdolahzadeh L, Saghari M, Malekzadeh R. In vivo tracking of 111 In-oxine labeled mesenchymal stem cells following infusion in patients with advanced cirrhosis.Nucl Med Biol. 2011;38(7):961-967.

23. Gotherstrom C, Ringden O, Tammik C, Zetterberg E, Westgren M, Le Blanc K. Immunologic properties of human fetal mesenchymal stem cells. Am J Obstet Gynecol 2004;190(1):239.
24. Götherström C, Westgren M, Shaw SW, Aström E, Biswas A, Byers PH, Mattar CN, Graham GE, Taslimi J, Ewald U, Fisk NM, Yeoh AE, Lin JL, Cheng PJ, Choolani M, Le Blanc K, Chan JK. Pre- and postnatal transplantation of fetal mesenchymal stem cells in osteogenesis imperfecta: a two-center experience. Stem Cells Transl Med. 2014;3(2):255-264.

25. Granero-Moltó F, Weis JA, Miga MI, Landis B, Myers TJ, O'Rear L, Longobardi L, Jansen ED, Mortlock DP, Spagnoli A. Regenerative effects of transplanted mesenchymal stem cells in fracture healing. Stem Cells 2009;27(8):1887-1898.

26. Hare JM, Fishman JE, Gerstenblith G, DiFede Velazquez DL, Zambrano JP, Suncion VY, Tracy M, Ghersin E, Johnston PV, Brinker JA, Breton E, Davis-Sproul J, Schulman IH, Byrnes J, Mendizabal AM, Lowery MH, Rouy D, Altman P, Wong Po Foo C, Ruiz P, Amador A, Da Silva J, McNiece IK, Heldman AW, George R, Lardo A. Comparison of allogeneic vs autologous bone marrow-derived mesenchymal stem cells delivered by transendocardial injection in patients with ischemic cardiomyopathy: the POSEIDON randomized trial. J Am Med Ass. 2012;308(22):2369-79.

27. Hare JM, Traverse JH, Henry TD, Dib N, Strumpf RK, Schulman SP, Gerstenblith G, DeMaria AN, Denktas AE, Gammon RS, Hermiller JB Jr, Reisman MA, Schaer GL, Sherman W. A randomized, double-blind, placebo-controlled, dose-escalation study of intravenous adult human mesenchymal stem cells (prochymal) after acute myocardial infarction. J Am CollCardiol. 2009;54(24):2277-2286.

28. Haynesworth SE, Baber MA, Caplan AI. Cytokine expression by human marrow- derived mesenchymal progenitor cells in vitro: effects of dexamethasone and IL-1 alpha. J Cell Physiol 1996;166(3):585-592.

29. Honczarenko M, Le Y, Swierkowski M, Ghiran I, Glodek AM, Silberstein LE. Human bone marrow stromal cells express a distinct set of biologically functional chemokine receptors. Stem Cells. 2006;24(4):1030-1041.

30. Horwitz EM, Gordon PL, Koo WK, Marx JC, Neel MD, McNall RY, Muul L, Hofmann T. Isolated allogeneic bone marrow-derived mesenchymal cells engraft and stimulate growth in children with osteogenesis imperfecta: Implications for cell therapy of bone. Proc Natl Acad Sci USA 2002;99(13):8932-8937.

31. Horwitz EM, Le Blanc K, Dominici M, Mueller I, Slaper-Cortenbach I, Marini FC, Deans RJ, Krause DS, Keating A. Clarification of the nomenclature for MSC: the International Society for Cellular Therapy position statement. Cytotherapy 2005;7:393-395.

32. Hung SC, Pochampally RR, Chen SC, Hsu SC, Prockop DJ. Angiogenic effects of human multipotent stromal cell conditioned medium activate the PI3K-Akt pathway in hypoxic endothelial cells to inhibit apoptosis, increase survival and stimulate angiogenesis. Stem Cells 2007;25(9):23632370 .

33. Ip JE, Wu Y, Huang J, Zhang L, Pratt RE, Dzau VJ. Mesenchymal stem cells use integrin $\beta 1$ not CXC chemokine receptor 4 for myocardial migration and engraftment. Mol Biol of Cell 2007;18(8):2873-2882. 
34. Ishihara A, Ohmine K, Weisbrode SE, Bertone AL. Effect of intra-medullar and intra-venous infusions of mesenchymal stem cells on cell engraftment by in-vivo cell tracking and osteoinductivity in rabbit long bones: a pilot study. Orthop Muscular Syst 2014;3(3).

35. Jackson JS, Golding JP, Chapon C, Jones WA, Bhakoo KK. Homing of stem cells to sites of inflammatory brain injury after intracerebral and intravenous administration: a longitudinal imaging study. Stem Cell Res Ther 2010;1(2):17.

36. Jin SZ, Liu BR, Xu J, Gao FL, Hu ZJ, Wang XH, Pei FH, Hong Y, Hu HY, Han MZ. Ex vivo-expanded bone marrow stem cells home to the liver and ameliorate functional recovery in a mouse model of acute hepatic injury. Hepatobiliary Pancreat Dis Int 2012;11(1):66-73.

37. Kadiyala S, Young RG, Thiede MA, Bruder SP. Culture expanded canine mesenchymal stem cells possess osteochondrogenic potential in vivo and in vitro. Cell Transplant 1997;6:125-134.

38. Kebriaei P, Isola L, Bahceci E, Holland K, Rowley S, McGuirk J, Devetten M, Jansen J, Herzig R, Schuster M, Monroy R, Uberti J. Adult human mesenchymal stem cells added to corticosteroid therapy for the treatment of acute graft-versus-host disease. Biol Blood Marrow Transplant 2009;15(7):804-811.

39. Kern S, Eichler H, Stoeve J, Klüter H, Bieback K. Comparative analysis of mesenchymal stem cells from bone marrow, umbilical cord blood, or adipose tissue. Stem Cells 2006;24:1294-1301.

40. Kinnaird T, Stabile E, Burnett MS, Shou M, Lee CW, Barr S, Fuchs S, Epstein SE. Local delivery of marrow-derived stromal cells augments collateral perfusion through paracrine mechanisms. Circulation 2004;109(12):1543-1549.

41. Kovach TK, Dighe AS, Lobo PI, Cui QJ. Interactions between MSCs and Immune Cells: Implications for Bone Healing. J Immunol Res 2015, Article ID 752510.

42. Lalu MM, McIntyre L, Pugliese C, Fergusson D, Winston BW, Marshall JC, Granton J, Stewart DJ. Safety of cell therapy with mesenchymal stromal cells (SafeCell): a systematic review and meta-analysis of clinical trials. PLoSOne 2012;7(10):e47559.

43. Lange C, Reimer R, Zustin J, Brunswig-Spickenheier B. Mesenchymal stromal cells protect from consequences of HSCT-transplantation preparatory irradiation: insights into possible mechanisms. Cell Ther Transplant 2016; 5(2):50-58.

44. Lapidot T. Mechanism of human stem cell migration and repopulation of NOD/SCID and B2mnull NOD/SCID mice. The role of SDF-1/CXCR4 interactions. Ann N Y Acad Sci 2001;938:83-95.

45. Le Blanc K, Tammik C, Rosendahl K, Zetterberg E, Ringden O. HLA expression and immunologic properties of differentiated and undifferentiated mesenchymal stem cells. Exp Hematol 2003;31(10):890-896.

46. Le Blanc K, Götherström C, Ringdén O, Hassan M, McMahon R, Horwitz E, Anneren G, Axelsson O, Nunn J, Ewald U, Nordén-Lindeberg S, Jansson M, Dalton A, Aström
E, Westgren M. Fetal mesenchymal stem-cell engraftment in bone after in utero transplantation in a patient with severe osteogenesis imperfecta. Transplantation 2005;79(11):16071614.

47. Le Blanc K, Frassoni F, Ball L, Locatelli F, Roelofs H, Lewis I, Lanino E, Sundberg B, Bernardo ME, Remberger M, Dini G, Egeler RM, Bacigalupo A, Fibbe W, Ringdén O. Mesenchymal stem cells for treatment of steroid-resistant, severe, acute graft-versus-host disease: a phase II study. Lancet 2008;371:1579-1586.

48. Lee RH, Pulin AA, Seo MJ, Kota DJ, Ylostalo J, Larson BL, Semprun-Prieto L, Delafontaine P, Prockop DJ. Intravenous hMSCs improve myocardial infarction in mice because cells embolized in lung are activated to secrete the anti-inflammatory protein TSG-6. Cell Stem Cell 2009;5(1):54-63.

49. Lee RH, Seo MJ, Pulin AA, Gregory CA, Ylostalo J, Prockop DJ. The CD34-like protein PODXL and alpha6-integrin (CD49f) identify early progenitor MSCs with increased clonogenicity and migration to infarcted heart in mice. Blood. 2009;113:816-826.

50. Li L, Zhang S, Zhang Y, Yu B, Xu Y, Guan Z. Paracrine action mediate theantifibrotic effect of transplanted mesenchymal stem cells in a rat model of global heart failure. Mol Biol Rep 2009;36(4):725-731.

51. Li MD, Atkins H, Bubela T. The global landscape of stem cell clinical trials. Regenerative Medicine 2014;9(1):27-39.

52. Liao Y, Zhang XL, Li L, Shen FM, Zhong MK. Stem cell therapy for bone repair: a systematic review and meta-analysis of preclinical studies with large animal models. Br J Clin Pharmacol 2014;78(4):718-726.

53. Lin Y, Hogan WJ. Clinical application of mesenchymal stem cells in the treatment and prevention of graft-versushost disease. Adv Hematol 2011;2011:427863.

54. Liu Y, Yang R, Shi S. Systemic infusion of mesenchymal stem cells improves cell-based bone regeneration via upregulation of regulatory T cells. Tissue Eng Part A 2014. 21 (3-4):498-509.

55. Madrigal M, Rao KS, Riordan NH. A review of therapeutic effects of mesenchymal stem cell secretions and induction of secretory modification by different culture methods. J Transl Med 2014;12:260.

56. Majumdar MK, Thiede MA, Mosca JD, Moorman M, Gerson SL. Phenotypic and functional comparison of cultures of marrow-derived mesenchymal stem cells(MSCs) and stromal cells. J Cell Physiol 1998; 176(1):57-66.

57. Makhoul G, Chiu R, Cecere R. Placental mesenchymal stem cells: a unique source for cellular cardiomyoplasty. Ann Thorac Surg. 2013; 95(5):1827-1833.

58. Martinet L, Fleury-Cappellesso S, Gadelorge M, Dietrich G, Bourin P, Fournié JJ, Poupot R. A regulatory crosstalk between Vgamma9 Vdelta2 T lymphocytes and mesenchymal stem cells. Eur J Immunol 2009; 39(3):752-762.

59. Maziarz RT, Devos T, Bachier CR, Goldstein SC, Leis JF, Devine SM, Meyers G, Gajewski JL, Maertens J, Deans RJ, Van't Hof W, Lazarus HM. Single and multiple dose 
MultiStem $^{\circledast}$ (Multi-Potent Adult Progenitor Cell) therapy prophylaxis of acute GVHD in myeloablative allogeneic hematopoietic cell transplantation: a phase I trial. Biol Blood Marrow Transplant 2014. pii: S1083-8791(14)01469-4.

60. Meisel R, Zibert A, Laryea M, Göbel U, Däubener W, Dilloo D. Human bone marrow stromal cells inhibit allogeneic T-cell responses by indoleamine 2,3-dioxygenase-mediated tryptophan degradation. Blood 2004;103(12):4619-4621.

61. Munns CF, Rauch F, Zeitlin L, Fassier F, Glorieux FH. Delayed osteotomy but not fracture healing in pediatric osteogenesisimperfecta patients receiving pamidronate. J Bone Miner Res 2004;19(11):1779-1786.

62. Murphy MB, Moncivais K, Caplan A. Mesenchymal stem cells: environmentally responsive therapeutics for regenerative medicine. Exp Mol Med. 2013;45:e54.

63. Muslimov AR, Mikhelashvili RT, Volchkov EV, Lepik KV, Sergeev VS, Afanasyev BV. Instant lysis of therapeutic mesenchymal stem cells after intravenous infusion: role of complement system and in vitro prevention strategies. Cell Ther Transplant 2016;5(1):68-69.

64. Nauta AJ, Westerhuis G, Kruisselbrink AB, Lurvink EG, Willemze R, Fibbe WE. Donor-derived mesenchymal stem cells are immunogenic in an allogeneic host and stimulate donor graft rejection in a nonmyeloablative setting. Blood 2006;108(6):2114-2120.

65. Nasef A, Mathieu N, Chapel A Frick J, François S, Mazurier C, Boutarfa A, Bouchet S, Gorin NC, Thierry D, Fouillard L. Immunosuppressive effects of mesenchymal stem cells: involvement of HLA-G. Transplantation 2007;84(2):231-237.

66. Nasef A, Mazurier C, Bouchet S, François S, Chapel A, Thierry D, Gorin NC, Fouillard L. Leukemia inhibitory factor: role in human mesenchymal stem cells mediated immunosuppression. Cell Immunol 2008;253(1-2):16-22.

67. Nauta AJ, Fibbe WE Immunomodulatory properties of mesenchymal stromal cells. Blood 2007;110:3499-06.

68. Nauta AJ, Westerhuis G, Kruisselbrink AB, Lurvink EG, Willemze R, Fibbe WE. Donor-derived mesenchymal stem cells are immunogenic in an allogeneic host and stimulate donor graft rejection in a nonmyeloablative setting. Blood. 2006;108(6):2114-2120.

69. Obermeyer TS, Yonick D, Lauing K. Stock SR, Nauer R, Strotman P, Shankar R, Gamelli R, Stover M, Callaci JJ.. Mesenchymal stem cells facilitate fracture repair in an alcohol-induced impaired healing model. J Orthop Trauma. 2012;26(12):712-718.

70. Ohab JJ, Fleming S, Blesch A, Carmichael ST. A neurovascular niche for neurogenesis after stroke. J Neurosci 2006;26(50):13007-13016.

71. Otsuru S, Gordon PL, Shimono K, Jethva R, Marino R, Phillips CL, Hofmann TJ, Veronesi E, Dominici M, Iwamoto M, Horwitz EM. Transplanted bone marrow mononuclear cells and MSCs impart clinical benefit to children with osteogenesis imperfecta through different mechanisms. Blood. 2012;120(9):1933-1941.
72. Pascucci L, Alessandri G, Dall'Aglio C. Mercati F, Coliolo P, Bazzucchi C, Dante S, Petrini S, Curina G, Ceccarelli P. Membrane vesicles mediate pro-angiogenic activity of equine adipose-derived mesenchymal stromal cells. Vet J 2014;202(2):361-366.

73. Phinney DG. Biochemical heterogeneity of mesenchymal stem cell populations: clues to their therapeutic efficacy. Cell Cycle 2007; 6:2884-2889.

74. Pittenger MF, Mackay AM, Beck SC, Jaiswal RK, Douglas R, Mosca JD, Moorman MA, Simonetti DW, Craig S, Marshak DR. Multilineage potential of adult human mesenchymal stem cells. Science 1999;284(5411):143-147.

75. Prigozhina TB, Khitrin S, Elkin G, Eizik O, Morecki S, Slavin S. Mesenchymal stromal cells lose their immunosuppressive potential after allotransplantation. Exp Hematol 2008;36(10):1370-1376.

76. Prockop DJ. Marrow stromal cells as stem cells for non-hematopoietic tissues. Science 1997;276:71-74.

77. Prockop DJ, Gregory CA, Spees JL. One strategy for cell and gene therapy: harnessing the power of adult stem cells to repair tissues. Proc Natl Acad Sci USA 2003;100 (Suppl 1):11917-11923.

78. Quevedo HC, Hatzistergos KE, Oskouei BN, Feigenbaum GS, Rodriguez JE, Valdes D, Pattany PM, Zambrano JP, Hu Q, McNiece I, Heldman AW, Hare JM. Allogeneic mesenchymal stem cells restore cardiac function in chronic ischemic cardiomyopathy via trilineage differentiating capacity. Proc Natl Acad Sci USA 2009;106(33):14022-14027.

79. Rafei M, Hsieh J, Fortier S, Li M, Yuan S, Birman E, Forner K, Boivin MN, Doody K, Tremblay M, Annabi B, Galipeau J. Mesenchymal stromal cell-derived CCL2 suppresses plasma cell immunoglobulin production via STAT3 inactivation and PAX5 induction. Blood 2008;112(13):49914998.

80. Rapp AE, Bindl R, Heilmann A, Erbacher A, Müller I, Brenner RE, Ignatius A. Systemic mesenchymal stem cell administration enhances bone formation in fracture repair but not load-induced bone formation. Eur Cell Mater 2015; 29:22-34.

81. Rehman J, Traktuev D, Li J, Merfeld-Clauss S, TemmGrove CJ, Bovenkerk JE, Pell CL, Johnstone BH, Considine RV, March KL. Secretion of angiogenic and antiapoptotic factors by human adipose stromal cells. Circulation 2004;109(10):1292-1298.

82. Repeated infusions of mesenchymal stromal cells in children with osteogenesis imperfecta (STOD3). https://clinicaltrials.gov/ct2/show/NCT01061099

83. Ries C, Egea V, Karow M, Kolb H, Jochum M, Neth P. MMP-2, MT1-MMP, and TIMP-2 are essential for the invasive capacity of human mesenchymal stem cells: differential regulation by inflammatory cytokines. Blood 2007;109(9):4055-4063.

84. Rüster B, Göttig S, Ludwig RJ, Bistrian R, Müller S, Seifried E, Gille J, Henschler R. Mesenchymal stem cells display 
coordinated rolling and adhesion behavior on endothelial cells. Blood. 2006;108(12):3938-3944.

85. Ryan JM, Barry FP, Murphy JM, Mahon BP. Mesenchymal stem cells avoid allogeneic rejection. J Inflamm (Lond) 2005;2:8.

86. Sato K, Ozaki K, Oh I Meguro A, Hatanaka K, Nagai T, Muroi K, Ozawa K. Nitric oxide plays a critical role in suppression of T-cell proliferation by mesenchymal stem cells. Blood 2007;109(1):228-234.

87. Schindeler A, McDonald MM, Bokko P, Little DG. Bone remodeling during fracture repair: The cellular picture. Semin Cell Dev Biol. 2008;19(5):459-466.

88. Sensebé L, Fleury-Cappellesso S. Biodistribution of mesenchymal stem/stromal cells in a preclinical setting. Stem Cells Int 2013;2013:678063.

89. Shabbir A, Zisa D, Suzuki G, Lee T. Heart failure therapy mediated by the trophic activities of bone marrow mesenchymal stem cells: a noninvasive therapeutic regimen. Am J Physiol Heart Circ Physiol 2009;296(6):H1888-97.

90. Shen L, Gao Y, Qian J, Sun A, Ge J. A novel mechanism for endothelial progenitor cells homing: The SDF-1/ CXCR4-Rac pathway may regulate endothelial progenitor cells homing through cellular polarization. Med Hypotheses 2011;76(2):256-258.

91. Sorrell JM, Baber MA, Caplan AI. Influence of adult mesenchymal stem cells onin vitro vascular formation. Tissue Eng Part A. 2009;15(7):1751-1761

92. Sotiropoulou PA, Perez SA, Gritzapis AD, Baxevanis CN, Papamichail M. Interactions between human mesenchymal stem cells and natural killer cells. Stem Cells 2006;24(1):74-85.

93. Spees JL, Olson SD, Ylostalo J et al. Differentiation, cell fusion, and nuclear fusion during ex vivo repair of epithelium by human adult stem cells from bone marrow stroma. Proc Natl Acad Sci USA 2003;100:2397-2402

94. Stagg J. Immune regulation by mesenchymal stem cells: two sides to the coin. Tissue Antigens 2007;69:1-9.

95. Suga H, Eto H, Shigeura T, Inoue K, Aoi N, Kato H, Nishimura S, Manabe I, Gonda K, Yoshimura K. IFATS collection: Fibroblast growth factor-2-induced hepatocyte growth factor secretion by adipose-derived stromal cells inhibits postinjury fibrogenesis through a c-Jun $\mathrm{N}$-terminal kinase-dependent mechanism. Stem Cells. 2009;27(1):238-249.

96. Sugiyama T, Kohara H, Noda M, Nagasawa T. Maintenance of the hematopoietic stem cell pool by CXCL12-CXCR4 chemokine signaling in bone marrow stromal cell niches. Immunity 2006;25(6):977-988.

97. Tang KC, Trzaska KA, Smirnov SV, Kotenko SV, Schwander SK, Ellner JJ, Rameshwar P. Down-regulation of MHC II in mesenchymal stem cells at high IFN-gamma can be partly explained by cytoplasmic retention of CIITA. J Immunol 2008;180(3):1826-1833.

98. Terada N, Hamazaki T, Oka M, Hoki M, Mastalerz DM, Nakano Y, Meyer EM, Morel L, Petersen BE, Scott EW. Bone marrow cells adopt the phenotype of other cells by spontaneous cell fusion. Nature 2002;416:542-545.

99. Toegel F, Weiss K, Yang Y, Hu Z, Zhang P, Westenfelder C. Vasculotropic, paracrine actions of infused mesenchymal stem cells are important to the recovery from acute kidney injury. Am J Physiol Renal Physiol 2007;292(5):F1626-1635.

100. von Bahr L, Batsis I, Moll G Hägg M, Szakos A, Sundberg B, Uzunel M, Ringden O, Le Blanc K. Analysis of tissues following mesenchymal stromal cell therapy in humans indicates limited long-term engraftment and no ectopic tissue formation. Stem Cells 2012;30(7):1575-1578.

101. von Lüttichau I, Notohamiprodjo M, Wechselberger A, Peters C, Henger A, Seliger C, Djafarzadeh R, Huss R, Nelson PJ. Human adult CD34- progenitor cells functionally express the chemokine receptors CCR1, CCR4, CCR7, CXCR5, and CCR10 but not CXCR4. Stem Cells Devel 2005;14(3):329-336.

102. Wang C, Chen C, Lin W. Direct intramyocardial injection of mesenchymal stem cell sheet fragments improves cardiac functions after infarction. Cardiovasc Res 2008;77(3):515-524.

103. Wang LT, Ting CH, Yen ML, Liu KJ, Sytwu HK, Wu K, Yen BL. Human mesenchymal stem cells (MSCs) for treatment towards immune- and inflammation-mediated diseases: review of current clinical trials. Journal of Biomedical Science 2016;23:76. DOI 10.1186/s12929-016-0289-5.

104. Wilson JG, Liu KD, Zhuo H, Caballero L, McMillan M, Fang X, Cosgrove K, Vojnik R, Calfee CS, Lee JW, Rogers AJ, Levitt J, Wiener-Kronish J, Bajwa EK, Leavitt A, McKenna D, Thompson BT, Matthay MA. Mesenchymal stem (stromal) cells for treatment of ARDS: a phase 1 clinical trial. Lancet Respir Med. 2015; 3(1): 24-32.

105. WMA Declaration of Helsinki - Ethical Principles for Medical Research Involving Human Subjects. Adopted by the 18th WMA General Assembly, Helsinki, Finland, June 1964 and amended by the: 29th WMA General Assembly, Tokyo, Japan, October 1975, 35th WMA General Assembly, Venice, Italy, October 1983, 41st WMA General Assembly, Hong Kong, September 1989, 48th WMA General Assembly, Somerset West, Republic of South Africa, October 1996, 52nd WMA General Assembly, Edinburgh, Scotland, October 2000, 53rd WMA General Assembly, Washington DC, USA, October 2002 (Note of Clarification added), 55th WMA General Assembly, Tokyo, Japan, October 2004 (Note of Clarification added), 59th WMA General Assembly, Seoul, Republic of Korea, October 2008, 64th WMA General Assembly, Fortaleza, Brazil, October 2013. http://www.wma. net/en/30publications/10policies/b3/

106. Wynn RF, Hart CA, Corradi-Perini C, O’Neill L, Evans CA, Wraith JE, Fairbairn LJ, Bellantuono I. A small proportion of mesenchymal stem cells strongly expresses functionally active CXCR4 receptor capable of promoting migration to bone marrow. Blood 2004;104(9):2643-2645.

107. Yagi H, Soto-Gutierrez A, Parekkadan B, Kitagawa Y, Tompkins RG, Kobayashi N, Yarmush ML. Mesenchymal stem cells: mechanisms of immunomodulation and homing. Cell Transplant 2010;19:667-679. 
108. Zander AR, Lange C, Westenfelder C. Mesenchymal stromal cells: main factor or helper in regenerative medicine? Kidney Int Suppl 2011; 1(3):74-76.

109. Zangi L, Margalit R, Reich-Zeliger S, Bachar-Lustig E, Beilhack A, Negrin R, Reisner Y. Direct imaging of immune rejection and memory induction by allogeneic mesenchymal stromal cells. Stem Cells 2009;27(11):2865-74.

110. Zigdon-Giladi H, Rudich U, Geller GM, Evron A. Recent advances in bone regeneration using adult stem cells. World J Stem Cells 2015; 7(3): 630-640.

\title{
Потенциальные клинические приложения мезенхимных стволовых клеток костного мозга в области костной регенерации
}

\author{
Владислав С. Сергеев \\ НИИ детской онкологии, гематологии и трансплантологии им. Р. М. Горбачевой, Первый Санкт-Петербургский \\ государственный медицинский университет им. И. П. Павлова, Санкт-Петербург, Россия
}

\section{Резюме}

Костный мозг (КМ) содержит популяцию резидентных клеток, именуемую «мультипотентными мезенхимными стволовыми клетками» (МСК). Эти адгезивные клетки могут быть выделены и культивированы в простых питательных средах, и способны к дифференцировке в жировые или костные клетки. До сих пор не доказана возможность массовой дифференцировки МСК в гепатоциты, клетки почек или головного мозга. В то же время рассматриваются два возможных варианта их клинического применения: (1) в качестве средства иммунной модуляции при реакции «трансплантат против хозяина» (РТПХ) и аутоиммунных болезнях или (2) как потенциального источника рост-стимулирующих факторов в специализированных тканях. Эта гетерогенная популяция может поддерживать гемопоэз путем секреции факторов роста, цитокинов и других биологически активных веществ. После введения МСК способны мигрировать в поврежденные ткани, тем самым способствуя их регенерации. Однако только малая часть МСК может достичь костномозговых ниш после внутривенной инфузии. Многочисленные эксперименты с МСК на различных моделях тканевых повреждений показали их способность подавлять апоптоз, вызванный гипоксией, химическими агентами и другими разрушительными факторами. Этот защитный эффект опосредован рядом секретируемых факторов роста, как, например, ГМ-КСФ. В большом числе клинических исследований показана безопасность терапии
МСК. Как клинические, так и экспериментальные исследования доказали слабую иммуногенность аллогенных МСК при их введении иммунокомпетентным реципиентам. К настоящему времени проводились инъекции культивированных МСК больным с острой РТПХ после трансплантации гемопоэтических клеток (ТГСК) и при некоторых аутоиммунных заболеваниях.

За последнее десятилетие несколько работ кались потенциальной эффективности МСК при введении в пораженные участки костей у пациентов с несовершенным остеогенезом (ОИ) - тяжелым наследственным заболеванием с нарушением структуры коллагена, приводящим к повышенной ломкости костей. Здесь представлены сведения о клиническом протоколе для оценки безопасности, иммуногенности и клиническ их эффектов МСК, вводимых больным ОИ в ходе корригирующей остеотомии. Можно допустить, что небольшая субпопуляция МСК сможет мигрировать в поврежденные участки, дифференцироваться в хондроциты и остеобласты и, тем самым, участвовать в процессах регенерации кости.

\section{Ключевые слова}

Мезенхимные стволовые клетки, биологическое распределение, секретируемые факторы, размножение в культуре, клиническое применение, несовершенный остеогенез. 